\title{
Improvement of Student Learning Outcomes through Use Google Classroom Media in Class VIII-4 Students MTsN 1 Kota Subulussalam
}

\author{
Candra Sihotang1, Abdul Hasan Saragih², Abdul Hamid K ${ }^{3}$ \\ ${ }^{1}$ MTsN 1 Kota Subulussalam, Indonesia \\ ${ }^{2,3}$ Universitas Negeri Medan, Indonesia \\ cand.otank90@gmail.com
}

\begin{abstract}
The purpose of this study is to improve student learning outcomes in Indonesian language lessons using google classroom media. The subjects of the study were students of class VIII-4 MTsN 1 Subulussalam City, totaling 32 people consisting of 14 men and 18 women. This research uses a case study qualitative research method. Data collection techniques using observation, tests, and documentation. Then contextual data is analyzed through procedures namely: data reduction, data presentation, and drawing conclusions. The results showed an increase in student learning outcomes in learning Indonesian. This can be seen from the increase in the percentage of student learning outcomes from before the action, cycle I, to cycle II. Before the action the number of students who reached the KKM was $56.25 \%$ or 18 people. In the first cycle there was an increase to $71.88 \%$ or 23 people. Then in the second cycle there was an increase to $87.50 \%$ or 28 students. It can be concluded that the use of the google classroom application can improve learning outcomes in Indonesian subjects in class VIII-4 MTSN 1 Subulussalam City in 2019/2020.
\end{abstract}

Keywords

google classroom; learning

outcomes; Indonesian

\section{Introduction}

Learning is a very important key in any educational endeavor in the context of developing the intellectual life of the nation. Education has a role in improving the quality of human resources. This is in accordance with Law No. 20 of 2003 concerning the national education system states that education is a conscious and planned effort to create an atmosphere of learning and learning process so that students actively develop their potential to have spiritual spiritual strength, self-control, personality, intelligence, noble character, and the necessary skills himself, society, nation and state.

Learning outcomes are achievements after the learning process. Learning outcomes show the quality of the learning process (Gil-Jaurena \& Kucina Softic, 2016). Likewise the opinion of (Chase, Marks, Malkiewich, \& Connolly, 2019) states learning outcomes are the results obtained by students after the learning process is indicated by the test scores given by the teacher after each finish providing learning material on one subject. Furthermore (Berns, Isla-Montes, Palomo-Duarte, \& Dodero, 2016) in their research concluded that in improving learning outcomes, teachers are advised to use appropriate and varied learning strategies in presenting materials and applications in learning activities. Factors that influence learning outcomes include internal factors: (1) Physiological factors, (2) Psychological factors, while external factors: (1) Environmental factors, (2) Instrumental factors (Dubickis \& Gaile-Sarkane, 2017). 
In addition to learning outcomes, student activity also needs to be considered in the learning process. The learning process really requires the activeness of students. Without the activeness of students, learning seems boring. According to (Demartini \& Dossena, 2016) states the activeness of students in learning is an important and fundamental issue that must be understood and developed by each teacher in the learning process. So that students' activeness needs to be explored from the potentials that they have actualized through their activities to achieve learning objectives. According to (Zhu, 2017) explained that activeness can improve learning outcomes. Based on the research it can be concluded that increasing student activity can be done in five stages. The five stages include class presentations, group or team collaboration, presentation of the results of discussions or games, working on quiz questions or tournaments, and the results of grades or awards. According to (Berns et al., 2016) draw conclusions that student learning activities have increased in learning. This is indicated by the increased activity of students during group discussions, namely when expressing opinions and cooperation.

In learning Indonesian, there are many teaching methods that can be used. However, these methods do not all fit into the subject matter being taught. Various media and methods used by teachers such as lecture methods, use of power points, discussions and questions and answers. But in reality the method is still lacking in facilitating students to study more seriously, especially learning Indonesian.

The development of information and communication technology in the industrial era 4.0 has had a major influence on the learning process. According to (Czerniewicz, Trotter, \& Haupt, 2019) in his research stated that technological developments provide changes to the teaching and learning process. An increasingly broad and sophisticated internet as a means to facilitate learning. Online-based learning is needed as a tool or tool to support the current learning process. One of the technology media that is often used today is the application on a device or mobile phone / cellphone. The results of the study (Birbal, Ramdass, \& Harripaul, 2018) showed that students who interacted a lot with applications in the apparatus more easily understood the contents of reading texts. Various kinds of learning media in the form of e-learning that exist today are not yet used by the teacher to the full. One example, the use of the google classroom application media can be used as a learning medium to help improve student learning outcomes. This media can be accessed only through a device. The design of the google classroom is familiar to students because they have used several products from Google via their Google Apps account (Chawinga, 2017).

The use of google classroom actually makes it easier for teachers to manage learning and convey information quickly and accurately to students (Hardiyana, 2015). Google classroom is designed for users, teachers and students. The advantages of the google classroom application compared to other applications is that the google classroom application can be used to create and manage classes, assignments, grades, and provide direct feedback. Students can monitor the material and class assignments given by the teacher. In addition, students can also share material and interact in class, send assignments and get input grades directly. Learning with the use of google classroom has advantages to facilitate students in learning. Rozak \& Albantani (2018) states that the learning process through Google classroom makes it easy for students and teachers in the learning process. Through Google Classroom there is a direct and clear communication network between the teacher and students, especially communication tasks and the material delivered. With the existence of the google classroom application, it is expected to make it easier for students to learn so as to improve their learning outcomes.

Observation of Indonesian language learning outcomes at MTsN 1 Subulussalam City showed very low student learning outcomes. The results of the daily assessment showed 
43.75\% of students scored below the Minimum Completeness Criteria (KKM <72). Some causes of problems are students having difficulty in learning, student learning time is still lacking, subject matter is very much, and students are less interested in reading books and doing exercises.

From the results of interviews with teachers in the field of study of Indonesian language stated that so far the learning process is still ongoing conventionally and not yet using technology. The presence of technology in the revosi 4.0 era can actually help the learning process. Teachers should be able to use technology to support face-to-face learning. For example, by combining face-to-face learning with e-learning or online learning.

Based on the description above, this research will present a learning method based on elearning or online, namely using the google classroom application to assist the learning process. Another reason for choosing google classroom media is that all students already have a mobile device to access the application. These devices are the property of the students themselves and some are still using their parents' devices. One of the strengths of Google classroom is that it allows paper savings. Work or documents used in class will be shared digitally. Besides being easy to use, the Google classroom application presents various features that support the learning process. Learning activities that can be done is to make automatic copies of documents for students, make assignments and immediately assess them. The advantages of the google classroom application compared to other applications, the google classroom application can be accessed free of charge and specifically designed to help teachers and students in learning. (Bralić \& Divjak, 2018) conclude that there are significant differences in learning outcomes between the experimental class using learning with the google classroom and the control class using only project-based learning.

\section{Research Methods}

This type of research is a classroom action research whose main focus is to improve learning outcomes seen from student activity by using the google classroom application in learning Indonesian. The source of the research data were students of class VIII-4 MTsN 1 Subulussalam in 2019/2020 Academic Year as many as 32 people, consisting of 14 men and 18 women.

The research plan to be carried out is to make a class in google classroom, upload learning material in google classroom, then students learn from the uploaded material, create groups during learning activities to assess student activity, students work on quiz 1 and quiz 2 to measure the ability of learning outcomes the student.

This researcher uses qualitative data, namely data in the form of words, sentences, and schemas. Data collection is done systematically and data collected in accordance with the problem under study. Data retrieval is done by observation, interviews, documentation, and tests. The results obtained through observation include: a) students calm down and listen to the teacher during learning activities, b) students are busy taking notes, c) students do not dare to ask d) students are afraid and less enthusiastic in answering questions, e) students are not ready to learn. Interviews were conducted with Indonesian language teachers. Documentation is done while learning takes place. Then the test is given in the form of an interactive test.

The effectiveness of online based learning is learning by using the google classoroom application as a learning medium in terms of two cycles. In the first cycle, the researchers used the google classroom application media as a medium or reference for learning Indonesian. In this cycle researchers conducted learning activities by uploading material, videos from YouTube, and quiz 1 to be done individually. Individual questions that will later 
be used as the value of learning outcomes in cycle I. In this second cycle researchers used Google classroom as a project in conducting learning activities, namely, making discussions in the Google classroom application. Making assignments and results will be displayed directly on the google classroom application, group presentations, and working on questions in the form of a quiz 2. The test questions are as a value of learning outcomes in the second cycle that was submitted at the previous meeting. Students are expected to be able to utilize the Google Classroom application for learning.

In addition, the data increased learning activeness seen from: a) answering questions, b) asking questions, ideas or ideas, c) working on problems, d) group presentations, e) refuting or agreeing on other students' ideas. From the indicators that have been mentioned then scores are made based on student learning activeness. While learning outcomes data are collected through the test method. The test is given by students to test how the ability of students in understanding Indonesian language learning. The test is given twice, namely in cycle 1 and cycle 2 to identify changes in student learning outcomes. Learning outcomes seen from the achievement of students against the minimum completeness criteria ( $\mathrm{MCM} \geq 72$ ).

\section{Discussion}

Discussion of problems and action hypotheses based on qualitative data analysis. The description in this discussion is divided into two parts, the first part reveals research findings based on the results of the data namely learning outcomes and activeness. While the second part of the discussion about the relationship of research results with previous related research.

\subsection{Results}

\section{a. Learning Outcomes}

After conducting research the data obtained an increase in Indonesian language learning outcomes in each cycle. The action taken is the use of the google classroom application to improve student learning outcomes. The aim is to make it easier for students to learn effectively, create new learning settings, and introduce students to online learning.

Table 1. Improved Learning Outcomes for Each Cycle

\begin{tabular}{|l|l|c|c|c|}
\hline No & Learning outcomes & Before Actions & Cycle I & Cycle II \\
\hline 1 & Average & 58,36 & 75,80 & 89,76 \\
\hline 2 & Complete (MCM & 15 student & 21 student & 29 student \\
& $>72)$ & $(46,88 \%)$ & $(65,63)$ & $(90,63)$ \\
\hline 3 & Not Complete & 17 student & 11 student & 3 student \\
& & $(53,13 \%)$ & $(34,38 \%)$ & $(9,38 \%)$ \\
\hline
\end{tabular}

Based on the results of data analysis, table 1 shows the increase in calculation results in each cycle. There is a difference in the average value in each cycle from before and after using the google classroom application. The average value obtained after the use of the google classroom application is 89,76 compared to the average value before using the google classroom only 58,36 has increased by 31,40 . That is because the lack of student learning time efficiently and students lack understanding of the material presented, so that the use of google classroom makes it easier for students to learn.

The number of students who reached the MCM after using the google classroom application were 29 people $(90.63 \%)$ and 3 people $(9.38 \%)$ got grades below the MCM. When compared with before using google classroom, students who reached MCM which only 15 people $(46.88 \%)$ and 17 students $(53.13 \%)$ got grades below MCM. The percentage 
of students completeness increased in cycle I by $18.75 \%$ and in cycle II by $25 \%$. Likewise with an increase in the average value in the first cycle of 78.3 and the average value of the second cycle of 85.5. This means that the success rate of using the google classroom application has had a significant effect on improving learning outcomes.

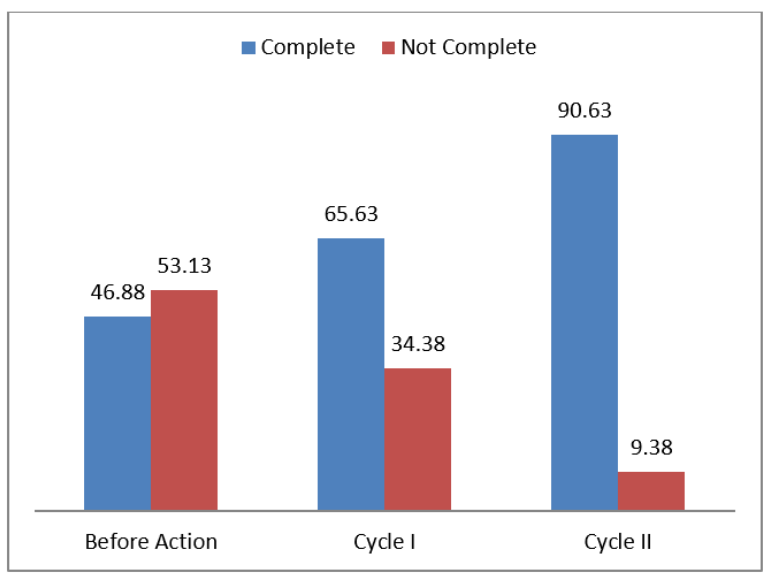

Figure 1. Graph of Improvement of Mastery Learning Outcomes

Based on the graph above it is known that students who complete KKM continue to increase from before the action which amounted to 15 people $(46.88 \%)$ increased to 21 people $(65.63 \%)$ in the first cycle then increased again to 29 people $(90.63 \%)$ in cycle II. The process of improvement per cycle can be seen from the results of the individual quiz scores in the first cycle and then seen from the quiz scores carried out in the second cycle. From the above results it can be concluded that the use of the google classroom application media can improve the learning outcomes of Indonesian students in class VIII-4 MTsN 1 Subulussalam City.

\section{b. Liveliness}

After conducting research the results obtained an increase in the activity of students learning Indonesian. Actions taken to improve student learning activeness is to measure how active students are in the process of learning activities. The aim is to create an atmosphere of learning that is interesting, active, and fun so that there is a willingness of students to learn. Improved learning activity can be seen from: a) answering questions or commenting in classrooms and the google classroom forum, b) asking questions, ideas or ideas, c) working on interactive quizzes, d) group presentations, e) refuting or approving other students' ideas. From the indicators that have been mentioned then scores are made based on student learning activeness. From the results of the grades students are categorized as very active students, active students, students are quite active and students are less active. Following are the data obtained during the class action taken:

Table 2. Increased Learning Activities

\begin{tabular}{|c|l|c|c|c|}
\hline No & \multicolumn{1}{|c|}{ Active Learning } & Before Action & Cycle I & Cycle II \\
\hline \multirow{2}{*}{1} & $\begin{array}{l}\text { Students are very active in } \\
\text { learning }\end{array}$ & $\begin{array}{c}2 \text { students out of } \\
32 \text { students } \\
(6,25 \%)\end{array}$ & $\begin{array}{c}\text { 9 students out of } \\
32 \text { students } \\
(28,13 \%)\end{array}$ & $\begin{array}{c}12 \text { students out } \\
\text { of } 32 \text { students } \\
(37,50 \%)\end{array}$ \\
\hline \multirow{2}{*}{2} & $\begin{array}{l}\text { Students are active in } \\
\text { learning }\end{array}$ & $\begin{array}{c}5 \text { students out of } \\
32 \text { students } \\
(15,63 \%)\end{array}$ & $\begin{array}{c}7 \text { students out of } \\
32 \text { students } \\
(21,88 \%)\end{array}$ & $\begin{array}{c}11 \text { students out } \\
\text { of } 32 \text { students } \\
(34,38 \%)\end{array}$ \\
\hline 3 & Students are quite active in & 10 students out & 11 students out & 7 students out of \\
\hline
\end{tabular}




\begin{tabular}{|c|l|c|c|c|}
\hline & learning & $\begin{array}{c}\text { of 32 students } \\
(31,25 \%)\end{array}$ & $\begin{array}{c}\text { of 32 students } \\
(34,38 \%)\end{array}$ & $\begin{array}{c}32 \text { students } \\
(21,88 \%)\end{array}$ \\
\hline \multirow{3}{*}{4} & Students are less active in & $\begin{array}{c}15 \text { students out } \\
\text { of 32 students } \\
(46,88 \%)\end{array}$ & $\begin{array}{c}5 \text { students out of } \\
32 \text { students } \\
(15,63 \%)\end{array}$ & $\begin{array}{c}2 \text { students out of } \\
32 \text { students } \\
(6,25 \%)\end{array}$ \\
\hline
\end{tabular}

Based on the table above, it can be stated that there was an increase in the activeness of students towards Grade VIII students of MTsN 1 Subulussalam City in learning Indonesian from before class action to after class action.

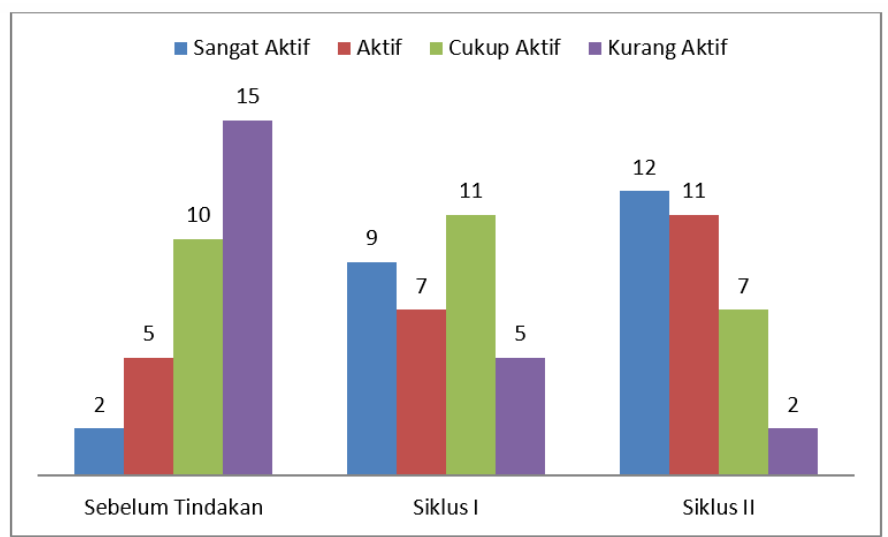

Figure 2. Data Percentage of Increased Student Activity in the Learning Process

From the graph above it can be seen that in the learning process each cycle has increased from before the action to the second cycle. In the first cycle students who were very active in the learning process increased by $21.88 \%$, students who were active in the learning process increased by $6.25 \%$, students who were quite active had increased by $3.13 \%$ and students who were less active had decreased at $31.23 \%$.

In cycle II, students who were very active experienced an increase of $9.37 \%$ when compared to cycle I (cycle II by $37.50 \%$, cycle I by $28.13 \%$ ). Active students experienced an increase of $12.50 \%$ when compared to the first cycle (second cycle was $34.38 \%$, first cycle was $21.88 \%$ ). Students who were quite active experienced a decrease of $12.5 \%$ when compared to the first cycle (first cycle was $34.38 \%$, second cycle was $21.88 \%$ ). Students who were less active experienced a decrease of $9.38 \%$ when compared to the first cycle (second cycle was $15.63 \%$ and the first cycle was $6.25 \%$ ).

\subsection{Discussion}

From the results of the data it is known that the implementation of e-learning based learning methods namely the use of the google classroom application is quite effective to complete the implementation of the learning approach. This implementation phase has been adjusted to the learning approach used so far, namely the contextual approach. Because in understanding a learning material must know the context of the core of each material learned so that the material delivered can be accepted by students. The first step, making teaching materials that have been adjusted clearly and can be understood by students, so students can learn easily. Then upload the material into the google classroom application. The material is about reading Indonesian language learning in the form of words or pdfs and videos about learning Indonesian as a reference for students to learn. In the google classroom application also provided a comment column that aims to open a discussion room between teachers and students. So students can easily ask questions about material that is considered difficult. Next to 
Classroom learning is adapted to the contextual approach through the google classroom application. These learning activities are quite effective. Various kinds of references for learning have been uploaded to the google classroom application. Students can learn easily at any time without having to deal with the teacher. In addition, students also feel happy and comfortable with the ease of accessing learning material.

Overall after the implementation of e-learning based Indonesian learning namely using the google classroom application can improve student learning outcomes. Improvement in each cycle can be seen based on the value of learning outcomes with Minimum Completion Criteria (> 72).

Based on the results achieved in the research conducted by researchers, it means that researchers strengthen the opinions of experts. The use of the google classroom application can improve the learning outcomes of Indonesian in class VIII-4 MTsN 1 Subulussalam City. Learning activities that can increase learning activeness also affect student learning outcomes. This supports the acceptance of classroom action research hypothesis that the use of the google classroom application can improve student learning outcomes in Indonesian.

\section{Conclusion}

Based on the results of the study it can be concluded that there is a positive effect of elearning learning on improving student learning outcomes. Then the conclusion is that the use of media using the Google classroom application can improve the learning outcomes of Indonesian students in class VIII-4 MTsN 1 Subulussalam.

Some suggestions that can be proposed include: 1) encouraging and motivating teachers to always try to develop new learning models or methods, 2) teachers are expected to be able to develop and deliver material and in managing classes by applying innovative learning, so that the learning process and outcomes can be continue to improve and, 3) should always develop learning models or methods that can stimulate students to be active and easier to understand the learning material.

\section{References}

Berns, A., Isla-Montes, J. L., Palomo-Duarte, M., \& Dodero, J. M. (2016). Motivation, students' needs and learning outcomes: a hybrid game-based app for enhanced language learning. SpringerPlus, 5(1), 1-23. https://doi.org/10.1186/s40064-016-29711

Birbal, D. R., Ramdass, D. M., \& Harripaul, M. C. (2018). Student Teachers' Attitudes towards Blended Learning. Journal of Education and Human Development, 7(2), 9-26. https://doi.org/10.15640/jehd.v7n2a2

Bralić, A., \& Divjak, B. (2018). Integrating MOOCs in traditionally taught courses: achieving learning outcomes with blended learning. International Journal of Educational Technology in Higher Education, 15(1). https://doi.org/10.1186/s41239-017-0085-7

Chase, C. C., Marks, J., Malkiewich, L. J., \& Connolly, H. (2019). How teacher talk guidance during Invention activities shapes students' cognitive engagement and transfer. International Journal of STEM Education, 6(1). https://doi.org/10.1186/s40594-0190170-7

Chawinga, W. D. (2017). Taking social media to a university classroom: teaching and learning using Twitter and blogs. International Journal of Educational Technology in Higher Education, 14(1). https://doi.org/10.1186/s41239-017-0041-6 
Czerniewicz, L., Trotter, H., \& Haupt, G. (2019). Online teaching in response to student protests and campus shutdowns: academics' perspectives. International Journal of Educational Technology in Higher Education, 16(1), 1-22. https://doi.org/10.1186/s41239-019-0170-1

Demartini, C., \& Dossena, C. (2016). Antecedents and consequences of the use of Facebook in learning contexts: a proposed framework. Technology, Innovation and Education, 2(1). https://doi.org/10.1186/s40660-016-0012-6

Dubickis, M., \& Gaile-Sarkane, E. (2017). Transfer of know-how based on learning outcomes for development of open innovation. Journal of Open Innovation: Technology, Market, and Complexity, 3(1). https://doi.org/10.1186/s40852-017-0053-4

Gil-Jaurena, I., \& Kucina Softic, S. (2016). Aligning learning outcomes and assessment methods: a web tool for e-learning courses. International Journal of Educational Technology in Higher Education, 13(1). https://doi.org/10.1186/s41239-016-0016-z

Hardiyana, A. (2015). Implementasi Google Classroom sebagai Alternatif dalam meningkatkan Mutu Pembelajaran di Sekolah. Karya Tulis Ilmiah, Cirebon: SMA N 1 Losari.

Rozak \& Azkia, M.A. (2018). Desain Perkuliahan Bahasa Arab Melalui google Classroom. Jurnal Pendidikan Bahasa Arab dan Kebahasaaraban, 5 (1), 83-102

Zhu, C. (2017). University student satisfaction and perceived effectiveness of a blended learning course. International Journal of Learning Technology, 12(1), 66-83. https://doi.org/10.1504/IJLT.2017.083996 